\author{
Pawee PopardowsKi ${ }^{1}$
}

\title{
Instrumenty prawne służące ochronie konkurencji w sektorze rolnym z perspektywy prawa Unii Europejskiej (zarys problematyki)
}

\section{Wprowadzenie}

Zagadnienia związane $\mathrm{z}$ zapewnieniem prawidłowego funkcjonowania konkurencji w sektorze rolnym z coraz mocniejszym natężeniem ujawniają się na tle prawodawstwa unijnego. Wskazuje się, że istnienie skutecznych instrumentów prawnych oddziałujących na kształtowanie się relacji rynkowych w obrocie produktami rolnymi przyczyni się do osiągnięcia wymiernych korzyści przez rolników (producentów rolnych) oraz konsumentów ${ }^{2}$. Wyróżniające jest przy tym, że dyskusji prowadzonej na poziomie unijnym ${ }^{3}$ problemowi ochrony konkurencji w rolnictwie nadaje się często szerszy wymiar. Akcentuje się bowiem inklinacje ogólnospołeczne związane z zapewnieniem prawidłowego funkcjonowania konkurencji. Między innymi w Rezolucji Parlamentu Europejskiego z dnia 26 marca 2009 r. w sprawie cen

1 Instytut Nauk Prawnych Polskiej Akademii Nauk.

2 Por. np. komunikat Komisji z dnia 9 grudnia 2008 r. „Ceny żywności w Europie” (COM (2008)0821) [opracowanie dostępne na stronie internetowej http://eurlex.europa.eu/LexUriServ/LexUriServ.do?uri=COM:2008:0821:FIN:PL:PDF (data dostępu: 21.12.2016 r.)]; analiza Parlamentu z dnia 20 października 2007 r. „Różnica pomiędzy cenami producenta a cenami płaconymi przez konsumenta”; Komunikat Komisji do Parlamentu Europejskiego, Rady, Europejskiego Komitetu Ekonomiczno-Społecznego i Komitetu Regionów z dnia 28 października 2009 r. „Poprawa funkcjonowania łańcucha dostaw żywności w Europie” [opracowanie dostępne na stronie internetowej http://eur-lex.europa.eu/LexUriServ/LexUriServ.do?uri=COM:2009:0591:FIN:PL:HTML (data dostępu: 21.12.2016 r.)]; Komunikat Komisji do Parlamentu Europejskiego, Rady, Europejskiego Komitetu Ekonomiczno-Społecznego i Komitetu Regionów „Poprawa funkcjonowania łańcucha dostaw żywności w Europie - konkluzje Prezydencji" [opracowanie dostępne na stronie internetowej http://register.consilium.europa.eu/doc/srv?l=EN\&f=ST\%208124\%202010\%20INIT (data dostępu: 21.12.2016 r.)].

3 W związku z kryzysem gospodarczym z pierwszej dekady XXI wieku, który swoim zasięgiem objął również unijne rynki rolne, na poziomie unijnym podejmowano liczne działania ewaluacyjne zmierzające do identyfikacji zasadniczych problemów regulacyjnych związanych z funkcjonowaniem konkurencji na rynkach rolnych. W tym celu ustanowiono Grupę Wysokiego Szczebla ds. Konkurencyjności Przemysłu Rolno-Spożywczego. Zob. decyzja Komisji 2008/359/WE z dnia 28 kwietnia 2008 r. ustanawiająca Grupę Wysokiego Szczebla ds. Konkurencyjności Przemysłu Rolno-Spożywczego (Dz.U. UE L 120 z 7.05.2008, s. 15), która została zmieniona przez decyzję Komisji 2009/785/WE z dnia 26 października 2009 r. zmieniająca decyzję 2008/359/WE ustanawiającą Grupę Wysokiego Szczebla ds. Konkurencyjności Przemysłu Rolno-Spożywczego w celu przedłużenia jej stosowania (Dz.U. UE L 280 z 27.10.2009, s. 56). Zadaniem grupy było badanie kwestii mających wpływ na obecna i przyszłą konkurencyjność przemysłu rolno-spożywczego i na tej podstawie opracowanie zaleceń odnoszących się do poszczególnych sektorów i skierowanych do osób odpowiedzialnych za wyznaczanie kierunków polityki na szczeblu unijnym. 
żywności podkreślono, że działania związane z utrzymaniem odpowiedniego poziomu cen producentów i konsumentów oraz zapewnieniem uczciwej konkurencji w obrocie produktami rolnymi powinny stanowić zasadniczy obszar oddziaływania organów unijnych ze względu na dążenie do realizacji dobra wspólnego ${ }^{4}$. Eksponowanie tego elementu sprawia, że problem konkurencji w rolnictwie nie jest redukowany do podejścia stricte ekonomicznego, lecz wiąże się z koniecznością uwzględnienia całego spektrum odniesień dotyczących produkcji i obrotu produktami rolnymi (tj. przede wszystkim kwestii bezpieczeństwa i niezależności w zakresie produkcji żywności, które wspomniany obszar badawczy wiążą z koniecznością zapewnienia odpowiedniej dochodowości produkcji rolnej oraz kwestii cen końcowych żywności, co wskazuje na korelację badanej problematyki z realizacją prawa człowieka do żywności) $)^{5}$.

Niniejsze opracowanie zmierza do zarysowania zasadniczych kwestii problemowych związanych z oddziaływaniem normatywnym na funkcjonowanie konkurencji w sektorze rolnym. Prowadzona analiza - co należy podkreślić - nie będzie się jednak ograniczała wyłącznie do badania zastanego stanu normatywnego w zakresie ochrony konkurencji w rolnictwie. W artykule zostaną również zasygnalizowane zasadnicze założenia koncepcyjne dotyczące wprowadzenia dyrektywy w sprawie nieuczciwych praktyk handlowych w relacjach między przedsiębiorcami w łańcuchu dostaw żywności ${ }^{6}$. Przedłożony projekt dyrektywy wskazuje bowiem na poszerzenie optyki prawodawcy unijnego w podejściu normatywnym do problemu ochrony konkurencji w rolnictwie unijnym. Poza dotychczas przyjmowanym

4 Rezolucja Parlamentu Europejskiego z dnia 26 marca 2009 r. w sprawie cen żywności w Europie (2008/2175(INI)), Dz. Urz. C 117 z 6 maja 2010 r., s. 180. Por. również G. Monti, The relationship between CAP and competition policy: Does EU competition law apply to agriculture? (SPEECH/03/537) [opracowanie dostępne w internecie na stronie http://europa.eu/rapid/press-release_SPEECH-03-537_en.htm?locale=en (data dostępu: 21.12.2016 r.)]. Zob. również Komunikat Komisji do Parlamentu Europejskiego, Rady, Europejskiego Komitetu Ekonomiczno-Społecznego i Komitetu Regionów z dnia 20 maja 2008 r. Reakcja na kwestię wzrostu cen żywności. Wskazówki dotyczące działań na szczeblu UE [opracowanie dostępne na stronie internetowej http://eur-lex. europa.eu/legal-content/PL/TXT/PDF/?uri=CELEX:52008DC0321\&from=EN (data dostępu: 21.12.2016 r.)]; Komunikat Komisji do Parlamentu Europejskiego, Rady, Europejskiego Komitetu Ekonomiczno-Społecznego i Komitetu Regionów z dnia 28 października 2009 r., Poprawa funkcjonowania łańcucha dostaw żywności w Europie, (COM/2009/0591) [opracowanie dostępne na stronie internetowej http://eur-lex.europa.eu/legal-content/PL/ TXT/HTML/?uri=CELEX:52009DC0591\&from=EN (data dostępu: 21.12.2016 r.)]; Komunikat Komisji do Parlamentu Europejskiego, Rady, Europejskiego Komitetu Ekonomiczno-Społecznego i Komitetu Regionów z dnia 20 maja 2008 r., Reakcja na kwestię wzrostu cen żywności. Wskazówki dotyczące działania na szczeblu UE (COM/2008/0321) [opracowanie dostępne na stronie internetowej http://eur-lex.europa.eu/legal-content/PL/TXT/ HTML/?uri=CELEX:52008DC0321\&from=EN (data dostępu: 21.12.2016 r.)].

5 Por. Komunikat Komisji do Parlamentu Europejskiego, Rady, Europejskiego Komitetu Ekonomiczno-Społecznego i Komitetu Regionów z dnia 20 maja 2008 r. Reakcja na kwestię wzrostu cen żywności. Wskazówki dotyczące działań na szczeblu UE, s. 8-9 oraz 12-13. Zob. również ogólne uwagi: S. McCorriston, Competition and food security, The State of Agricultural Commodity Markets 2015-16, Food and Agriculture Organization of the United Nations (FAO) [raport dostępny na stronie internetowej: http://www.fao.org/3/a-i5225e.pdf (data dostępu: 21.12.2016 r.)]; R. Sexton, S. McCorriston, S.H. Wang, Agricultural trade liberalization and economic development: the role of downstream market power, „Agricultural Economics” 2007, v. 36, nr 2, s. 253-270; Y. Chen, Trade, Food Security, and Human Rights. The Rules of International Trade in Agricultural Products and Evolving World Food Crisis, Dorchester 2014; A.R. Ganesh, The Right to Food and Buyer Power, „German Law Journal” 2010, nr 11, s. 1191 i n. 
podejściem, które skupia się na zagadnieniach ceny i struktury rynku, zainteresowaniem regulacyjnym prawodawcy unijnego obejmowane zostają również zagadnienia dotyczące wartościowania relacji rynkowych w obrocie produktami rolnymi (zwalczanie nieuczciwych praktyk w dostawach żywności).

\section{Przesłanki wyodrębnienia sektora rolnego w podejściu regulacyjnym do kwestii ochrony konkurencji}

Dla rolnictwa unijnego wyróżniające jest stosowanie przez prawodawcę unijnego podejścia sektorowego do kwestii ochrony konkurencji w rolnictwie. Wiąże się to $\mathrm{z}$ dostrzeżeniem swoistej autonomiczności rolnictwa w zakresie celów i problemów regulacyjnych.

W poszukiwaniu uzasadnienia dla takiego stanu rzeczy w piśmiennictwie eksponuje się zróżnicowane motywy. Na ogół za ratio zastosowanego przez prawodawcę unijnego autonomicznego ujęcia problematyki ochrony konkurencji w rolnictwie uznaje się szczególny charakter procesu wytwórczego oraz właściwości funkcjonowania rynku rolnego ${ }^{7}$. Stanowisko to jest przy tym uzupełniane przez odwoływanie się do szeroko rozumianych wartości społecznych ${ }^{8}$ dostrzeganych w tym obszarze oraz akcentowanie konieczności stworzenia odpowiednich uwarunkowań pozwalających na ich właściwą realizację i ochronę 9 . Podparciem dla tej tezy jest również

Np. E. Kosiński, Rolnictwo a publicznoprawna ochrona konkurencji w wybranych systemach prawnych (cz. I), „Kwartalnik Prawa Publicznego” 2005, nr 1-2, s. 190-191; M. Pohorille, Interwencjonizm w rolnictwie kapitalistycznym, Warszawa 1964, s. 50-58; B. Buhr, Economics of Antitrust in An Era of Global Agri-Food Supply Chains: Litigate, Legislate and/or Facilitate?, „Drake Journal of Agricultural Law” 2010, v. 15, nr 1, s. 33-35; M. Adamowicz, J. Król, Ochrona konkurencji a rynek rolny, Warszawa 1998, s. 72-75. W tym względzie wskazuje się m.in. na: 1) okresowość produkcji rolnej i wynikające z tego nadwyżki podażowe. Prowadzi to do istotnych trudności ze zbytem produktów rolnych; 2) niską elastyczność cenową. Popyt i podaż produktów rolnych nie są wrażliwe na zmiany cen. W konsekwencji spadek cen nie przekłada się w sposób bezpośredni na wzrost popytu ani spadek podaży zarówno w aspekcie długo-, jak i krótkoterminowym; 3) nieadekwatność pomiędzy wielkością produkcji a popytem. Na skutek rozwoju technologii rolniczej występuje ciągły wzrost zdolności produkcyjnych przy jednoczesnej stałej wielkości popytu na produkty rolne. W wielu krajach występują nadwyżki produkcyjne, co powoduje presję w zakresie poszukiwania rynków zbytu; 4) niska dochodowość produkcji rolnej. Wysokość dochodu uzyskiwana przez rolników nie zawsze odpowiada kosztom produkcji i zbytu produktów rolnych.

8 W literaturze podkreśla się, że cechą charakterystyczną rolnictwa jest występowanie licznych efektów zewnętrznych. W tej kategorii wyróżnia się wszystkie niezamierzone skutki powstające przy wytwarzaniu dóbr w toku działalności gospodarczej. Ich podstawową cechą jest to, że nie stanowią one przedmiotu obrotu handlowego, a tym samym koszty ponoszone przez rolników w związku z występowaniem efektów zewnętrznych nie znajdują kompensacji w rynku (nie są one uwzględniane w cenie produktów rolnych). Wśród efektów zewnętrznych działalności rolniczej wymienia się: 1) koszty zewnętrzne (ujemne efekty zewnętrzne). Koszty te powodowane są przez: umniejszenie (dobrostanu) środowiska przyrodniczego i wartości (dobrostanu) społeczno-kulturowego oraz umniejszenie korzyści ekonomicznych innych uczestników procesu gospodarczego; 2) dobra publiczne (dodatnie efekty zewnętrzne) związane przede wszystkim ze środowiskiem naturalnym oraz społeczno-kulturowym; 3) jakość żywności. Pomijanie zaś znaczenia tych czynników prowadzi do rozbieżności w zakresie postrzegania optimum ekonomicznego i optimum społecznego w rolnictwie. Zob. szerzej w tej kwestii: J.S. Zegar, Kategoria optymalności w rozwoju rolnictwa. Współczesne wyzwania, „Roczniki Nauk Rolnych Seria G” 2010, z. 3, s. 301310; D. Komorowska, Prawidłowości rozwoju rolnictwa a rozwój współczesnego rolnictwa, „Problemy Światowego Rolnictwa” 2014, t. 14, z. 3, s. 105-108; F. Vanni, Agriculture and Public Good. The Role of Collective Action, Dordrecht - Heidelberg - London - New York 2014, s. 1-17.

9 Na ten aspekt uwagę zwracają m.in. M. Pohorille, Interwencjonizm w rolnictwie..., op. cit., s. 59-60; M. Adamowicz, J. Król, Ochrona konkurencji..., op. cit., s. 72; A. Reich, The Agricultural Exemption in Antitrust Law: a Comparative Look at the Political Economy of Market Regulation, „Texas International Law Journal” 2007, v. 42, nr 3, 
odwołanie się do implikacji ekonomicznych, społecznych i politycznych związanych z funkcjonowaniem sektora rolnego. Ten kontekst ma przemawiać za ,szczególnością" sektora rolnego, a tym samym uzasadniać rozbudowaną interwencję państwową w tej sferze gospodarki (także w obszarze zagadnień związanych z ochroną konkurencji) ${ }^{10}$.

Uzasadnienie dla sektorowego podejścia do kwestii ochrony konkurencji w rolnictwie wywodzi się także z przesłanki o charakterze instytucjonalnym. Wskazuje się, że stosowanie szczególnych reguł konkurencji w rolnictwie znajduje swoje oparcie w odrębnym kształtowaniu się polityki konkurencji i polityki rolnej ${ }^{11}$. Każda z tych polityk w swoim rozwoju historycznym eksponowała odmienne cele oraz przyjmowała zróżnicowane instrumenty ich realizacji. Pomimo nakładania się płaszczyzn oddziaływania, różnice występujące pomiędzy nimi są na tyle istotne, że nie jest możliwa ich jednoczesna realizacja w obrębie sektora rolnego. Wynika to z tego, że polityka rolna jest mocno osadzona w płaszczyźnie dążeń społecznych, co sprawia, że kwestia efektywności ekonomicznej - kluczowa z perspektywy realizacji polityki konkurencji - nie ma dla niej priorytetowego znaczenia ${ }^{12}$. W związku z tym konieczne było stworzenie szczególnych rozwiązań normatywnych, które służą wkomponowaniu instrumentów ochrony konkurencji w specyfikę celów i instrumentów właściwych dla polityki rolnej ${ }^{13}$.

s. 844; S. Ennis, Competition and Regulation in Agriculture, "OECD Journal of Competition Law and Policy” 2007, v. 9, nr 2, s. 102; J.D. Gutiérrez Rodríguez, Competition law goals in agricultural markets: a Latin America perspective, (w:) D. Zimmer (red.), The Goals of Competition Law, Cheltenham 2012, s. 450-451; G. Monti, The relationships between CAP and competition policy. Does EU competition law apply to agriculture? COGECA Conference Helsinki Fair Trade, 13 November 2003, s. 1 (EU Press SPEECH/03/527).

10 E. Kosiński, Rodzaje i zakres sektorowych wyłączeń zastosowania ogólnych reguł konkurencji, Poznań 2007, s. 312.

11 S. Ennis, Competition..., op. cit., s. 102. Podobny kierunek przyjmowany jest również na tle opracowania: Competition and Regulation in Agriculture: Monopsony Buying and Joint Selling, OECD Competition Law \& Policy (DAF/COMP(2005)44), s. 1 [opracowanie dostępne w internecie na stronie: http://www.oecd.org/regreform/sectors/35910977.pdf (data dostępu: 18.08.2016 r.)].

12 Tak pośrednio również E. Kosiński, Rodzaje i zakres..., op. cit., s. 312.

13 Zaznaczyć w tym miejscu również należy, że wspomniana odrębność sektora rolnego w kwestii ochrony konkurencji pośrednio wynikała także z tego, iż w początkowym etapie rozwojowym polityki rolnej nie dostrzegano konieczności bezpośredniego odwoływania się do rozwiązań normatywnych właściwych dla polityki konkurencji. Podejście wynikało z tego, że rolnictwo wykazuje cechy zbliżone do modelu konkurencji doskonałej (zatomizowana struktura rynku, wynikające $z$ charakteru produkcji rolnej istotne ograniczenia potencjału produkcyjnego i możliwości uzyskiwania przewagi nad konkurentami, homogeniczny charakter produktu rolnego) (szerzej w kwestii postrzegania rolnictwa jako struktury zbliżonej do modelu konkurencji doskonałej w aspekcie krytycznym: M.E. Sykuta, The Fallacy of "Competition" in Agriculture, (w:) H.J. Jones Jr. (red.), The Goals of Competition Law, Cheltenham 2012, s. 56 i n. oraz D.G. Johnston, Competition in Agriculture: Fact or Fiction, „The American Economic Review" 1954, v. 44, nr 2, s. 107-115). Wobec tego - z powołaniem się na specyfikę tego sektora - dostrzegano, że w obszarze tym z mniejszą intensywnością występują tendencje do podejmowania działań ograniczających konkurencję. Podkreślenia wymaga również to, że „kontekst” rolny miał istotne znaczenie w kształtowaniu się regulacji dotyczących ochrony konkurencji. O ile w początkowym okresie rozwoju nie dostrzegano znaczących problemów z ochroną konkurencji w obrębie sektora rolnego, to jednocześnie wskazywano na zagrożenia wynikające z powiązania funkcjonalnego pomiędzy sektorem rolnym a innymi sektorami gospodarki. Por. J. Lauck, Toward an Agrarian Antitrust: A New Direction for Agricultural Law, „North Dakota Law Review” 1999, v. 75 , s. 450 i n. 
Poza uwarunkowaniami instytucyjnymi zasadniczych motywów uprzywilejowania sektora rolnego w kwestii ochrony konkurencji upatruje się w sferze uwarunkowań społeczno-gospodarczych. W związku z występującymi słabościami rolnictwa wynikającymi z oparcia produkcji rolnej na właściwościach środowiska naturalnego, niską elastycznością cenową, powstawaniem okresowych nadwyżek produkcyjnych oraz słabą dochodowością produkcji konieczne jest podejmowanie rozbudowanych działań interwencyjnych ${ }^{14}$. Interwencja państwowa często nastawiona jest na utrzymanie lub zwiększenie potencjału produkcyjnego (proprodukcyjny charakter interwencji). Powoduje to, że polityka rolna często orientowana jest na rynek ${ }^{15}$. Dla potrzeb realizacji celów polityki rolnej przyjmowano rolę aktywnego uczestnika mechanizmu rynkowego. Rynek produktów został zatem podporządkowany celom polityki rolnej. Oznacza to, że instrumenty wsparcia realizowane w obrębie polityki rolnej (szczególnie dotyczące realizacji dominującej dotychczas polityki proprodukcyjnej) nie zawsze były zgodne z zasadniczymi założeniami ideowymi dotyczącymi ochrony konkurencji. Właściwe dla prawa konkurencji odwoływanie się do efektywności ekonomicznej jako celu nadrzędnego interwencji państwa w procesy gospodarcze nie jest w pełni absorbowane w odniesieniu do rolnictwa ${ }^{16}$. Znaczące oddziaływanie czynników społecznych, politycznych i kulturowych powoduje, że zasadniczym odniesieniem dla polityki rolnej jest kwestia konkurencyjności społecznej, która wyraża się w dążeniu do osiągnięcia optimum społecznego (dobrobytu społecznego). Ten kontekst sprawia, że w rolnictwie występuje swoista dwoistość odniesień, gdyż nie można pomijać znaczenia czynnika rynkowego, to jednocześnie nie można rynku traktować jako wyłączny regulator stosunków społecznych i gospodarczych w rolnictwie ${ }^{17}$. Determinuje to podejście do kwestii ochrony konkurencji, gdyż właściwy dla rolnictwa złożony kontekst uwarunkowań społecznych i gospodarczych wymaga tworzenia rozwiązań szczególnych, które: 1) pozwolą na realizowanie dobrobytu społecznego; 2) umożliwią (równoczesną) realizację zadań służących osiągnięciu optimum ekonomicznego ${ }^{18}$.

14 E. Kosiński, Rolnictwo..., op. cit., s. 190-191; M. Adamowicz, J. Król, Ochrona konkurencji..., op. cit., s. 72-75.

15 Zob. szerzej E. Tomkiewicz, (w:) D. Miąsik, N. Półtorak, Traktat ustanawiający Wspólnotę Europejską. Tom I (art. 1-160), Warszawa 2008, s. 754-761.

16 Por. J.S. Zegar, Konkurencyjność ekonomiczna versus konkurencyjność społeczna w rolnictwie, (w:) J. Sokołowski, M. Sosnowski, A. Żabiński (red.), Polityka ekonomiczna, Warszawa 2012, s. 564-565.

17 Ibidem, s. 572.

18 J.S. Zegar, Kategoria optymalności op. cit., s. 305-306. Autor ten wskazuje, że w istocie sygnalizowany problem w sektorze rolnictwa dotyczy poszukiwania koherencji pomiędzy interesami prywatnymi poszczególnych grup funkcjonujących w obrębie rynku rolnego (rolnicy i producenci rolni), których wyznacznikiem jest kategoria optimum ekonomicznego, a interesem społecznym uwzględniającym powiązanie z rolnictwem wartości o charakterze ogólnospołecznym (dążenie do osiągnięcia optimum społecznego). 


\section{Zasadnicze problemy regulacyjne dotyczące ochrony konkurencji w rolnictwie}

Nie budzi większych zastrzeżeń stwierdzenie, że od momentu, w którym produkt rolny został włączony w proces wymiany handlowej, funkcjonowanie sektora rolnego kształtowane jest przez oddziaływanie mechanizmu rynkowego i związane z nim prawa ekonomii. Zachowania rolników (producentów rolnych) wyznaczane są przez dążenie do maksymalizacji korzyści ekonomicznych z prowadzonej produkcji rolnej.

Powyższy kontekst sprawia, że w rolnictwie, podobnie jak w innych sektorach gospodarki, mamy do czynienia $\mathrm{z}$ akcentowaniem znaczenia korzyści, jakie wynikają z istnienia wolnej i uczciwej konkurencji oraz - co stanowi konsekwencję wcześniejszego spostrzeżenia - uznaniem konieczności kreowania rozwiązań normatywnych służących ochronie konkurencji przed zagrożeniami o charakterze wewnętrznym (rynkowym) i pozarynkowym. W obrębie tego sektora gospodarki występują również zjawiska ograniczające konkurencję, które prowadzą do obniżenia jego efektywności, wzrostu cen produktów rolnych oferowanych konsumentom oraz godzą w inne cele związane przez prawodawcę z tą formą aktywności gospodarczej.

Wśród zasadniczych wyzwań związanych z ochroną konkurencji w rolnictwie należy przede wszystkim wskazać na zagadnienia będące konsekwencją włączenia tego sektora w ramy złożonego obszaru gospodarczego zajmującego się przetwórstwem i dystrybucją żywności ${ }^{19}$. Udział rolnictwa w tzw. łańcuchu produkcji i dystrybucji żywności stanowi pochodną następującego procesu uprzemysłowienia produkcji żywności. Współcześnie wytwór produkcji rolniczej (produkt rolny) nie zawsze jest tożsamy z dobrem oferowanym ostatniemu odbiorcy na rynku (konsumentowi), gdyż produkt żywnościowy jest dobrem wysokoprzetworzonym. Pociąga to za sobą istotne implikacje w relacji rynkowej. Na skutek postępującego procesu uprzemysłowienia produkcji żywności nastąpiło zerwanie bezpośredniej relacji między rolnikiem (producentem rolnym) a konsumentem ${ }^{20}$. Zjawisko to potęgują przy tym ograniczenia wynikające ze specyfiki produkcji rolnej. Oparcie jej na walorach środowiska naturalnego prowadzi do związania terytorialnego i ograniczeń w zakresie poszukiwania przez rolnika rynków zbytu ${ }^{21}$. W konsekwencji obserwowane jest zjawisko ,uzależnienia” rolnictwa w relacjach gospodarczych z sektorem przetwórstwa żywności oraz sprzedaży detalicznej22. Ze względu na zatomizowa-

19 Tak wprost np. M. Pohorille, Interwencjonizm w rolnictwie..., op. cit., s. 53-55; D.L. Moss, C.R. Taylor, Short Ends of the Stick: The Plight of Growers and Consumers in Concentrated Agricultural Supply Chains, „Wisconsin Law Review" 2014, nr 1, s. 339-341; J. Lauck, Toward an Agrarian Antitrust..., op. cit., s. 453-456.

20 M. Pohorille, Interwencjonizm w rolnictwie..., op. cit., s. 53.

21 Por. D.L. Moss, C.R. Taylor, Short Ends of the Stick..., op. cit., s. 339-343; J. Lauck, Toward an Agrarian Antitrust..., op. cit., s. 466-474.

22 Dotyczy to przede wszystkim akcentowanego w badaniach empirycznych i teoretycznych związania w relacjach handlowych rolnika i sklepów wielkopowierzchniowych oraz występującego zjawiska narzucania przez te ostatnie niekorzystnych warunków zawierania umów poprzez wykorzystywanie przez nie pozycji dominującej. 
ną strukturę rolnicy (producenci rolni) nie mają siły rynkowej, która pozwalałaby im na minimalizowanie presji cenowej wywieranej ze strony nabywców ich dóbr (przetwórców żywności, hurtowników, sieci sklepów wielkopowierzchniowych) ${ }^{23}$. Posiadana przez przetwórców żywności, hurtowników, sieci wielkopowierzchniowe pozycja rynkowa pozwala im na narzucanie niekorzystnych warunków wymiany handlowej (przede wszystkim w zakresie ceny) wobec rolników. Wyrazem takiego stanu rzeczy jest zjawisko tzw. rozwarstwienia nożyc cenowych (wraz ze wzrostem cen produktów żywnościowych nabywanych przez konsumentów następuje jednoczesne obniżenie cen, po których sprzedawany jest przez rolników produkt rolny). Oznacza to, że korzyści ekonomiczne związane z obrotem produktami żywnościowymi kumulowane są przez podmioty uczestniczące na pośrednim szczeblu produkcji i dystrybucji żywności (przetwórcy, hurtownicy, podmioty zajmujące się sprzedażą detaliczną) ${ }^{24}$.

\section{Problem ochrony konkurencji w rolnictwie z perspektywy regulacji TFUE}

Kwestie ochrony konkurencji oraz funkcjonowania sektora rolnego od samego początku stanowiły istotny obszar zainteresowania regulacyjnego w ramach tego procesu. Oba zagadnienia traktowano jako fundamenty dla kreowanej więzi gospodarczej pomiędzy państwami członkowskimi ${ }^{25}$. Znaczenie tych zagadnień znalazło swoje bezpośrednie odzwierciedlenie na tle regulacji traktatowej poprzez nadanie im statusu odrębnych polityk ${ }^{26}$. Charakterystyczne jest, że już w początkowej fazie kształtowania się procesu integracji europejskiej dostrzegano odmienność sektora

23 B.L. Buhr, Economics of Antitrust..., op. cit., s. 33-34.

24 M. Pohorille, Interwencjonizm w rolnictwie..., op. cit., s. 55.

25 W odniesieniu do polityki rolnej wprost wskazuje się, że polityka ta stanowiła pierwszą i przez długi czas jedyną politykę sektorową tworzonej EWG (A. Jurcewicz, (w:) A. Jurcewicz, B. Kozłowska, E. Tomkiewicz, Polityka rolna Wspólnoty Europejskiej w świetle ustawodawstwa i orzecznictwa, Warszawa 1995, s. 44). Niekiedy akcentuje się przy tym, że „zajmowała ona centralne miejsce i odgrywała główną rolę w funkcjonowaniu ówczesnej EWG i to zarówno z politycznego, społecznego, jak i prawnego punktu widzenia" (tak A. Jurcewicz, Traktatowe podstawy unijnego prawa rolnego w świetle orzecznictwa. Zagadnienia wybrane, Warszawa 2013, s. 11). Znaczenie WPR wiąże się z tym, że polityka ta stanowiła i nadal stanowi zasadniczy element oddziaływania na rolnictwo unijne nie tylko w aspekcie normatywnym (poprzez kreowanie dla niego jednorodnych rozwiązań regulacyjnych), ale także w aspekcie funkcjonalnym wobec włączenia rolnictwa poszczególnych państw członkowskich w ramy wspólnej organizacji rynkowej (R. Schütze, From Dual to Cooperative Federalism. The Changing Structure of European Law, Oxford 2009, s. 215-224). Również wśród wypowiedzi dotyczących polityki konkurencji wskazuje się na jej fundamentalne znaczenie dla tworzenia rynku wewnętrznego. W tym względzie podkreśla się między innymi, że od samego początku tworzenia ram prawnych dla integracji gospodarczej dążono do tego, aby w miejsce znoszonych barier celnych i ograniczeń ilościowych oraz innych ograniczeń w handlu między państwami członkowskimi nie następowało ich zastępowanie poprzez ograniczenia będące efektem antykonkurencyjnych działań przedsiębiorców lub państw. Działanie mechanizmu konkurencji traktowano bowiem jako fundament dla tworzonego w ten sposób wspólnego rynku, który oparty miał być na założeniach właściwych dla idei wolnego rynku.

26 Por. art. 38-47 Traktatu ustanawiającego Europejską Wspólnotę Gospodarczą, podpisanego w Rzymie w dniu 25 marca 1957 r. w odniesieniu do WPR (obecnie art. 38-44 TFUE) oraz art. 85-94 TEWG statuujące podstawy normatywne polityki konkurencji (wspólne reguły konkurencji - obecnie 101-109 TFUE). 
rolnego i wynikającą z tego konieczność stosowania odrębnego ujęcia regulacyjnego, które będzie adekwatne do celów przyjmowanych przez politykę rolną ${ }^{27}$.

W odróżnieniu od podejścia przyjmowanego dla innych sektorów objętych procesem integracji - już od momentu jej powołania - WPR oparta była na modelu integracji pozytywnej, wyrażającym się w rozbudowanej interwencji w relacjach wewnętrznych i silnej protekcji w relacjach zewnętrznych ${ }^{28}$. Przyjęty model zakładał zatem zindywidualizowane podejście do kwestii funkcjonowania rolnictwa europejskiego, w którym zasadniczą rolę przypisywano aktywnemu oddziaływaniu Wspólnoty (UE) na zjawiska gospodarcze występujące w tym sektorze ${ }^{29}$.

Odmienności związane z przyjmowanym sposobem oddziaływania na rolnictwo europejskie rzutowały także na kwestię stosowania w tym obszarze rozwiązań dotyczących ochrony konkurencji (reguł konkurencji). Pamiętać należy, że włączenie rolnictwa $\mathrm{w}$ ramy procesu integracji wiązało się z uznaniem, iż działanie tego sektora będzie następowało z uwzględnieniem wyznaczanych w płaszczyźnie traktatowej i mających wymiar ponadsektorowy ram regulacyjnych niezbędnych dla utworzenia i zapewnienia prawidłowego funkcjonowania rynku wewnętrznego ${ }^{30}$. Równocześnie akcentowano szczególny charakter sektora rolnego, co prowadziło do przyjęcia podejścia zindywidualizowanego (sektorowego), które jest realizowane w ramach WPR (art. 38 ust. 2 TFUE). W odniesieniu do sektora rolnego, w procesie

Zob. ogólnie na tle podejścia sektorowego w ramach procesu integracji europejskiej: R. Barents, J.P. Slot, Sectoral Policies, (w:) P.J.G. Kapteyn, A.M. McDonnell, K.J.M. Mortelmans, C.W.A. Timmermans, L.A. Geelhoed (red.), The Law of European Union and European Communities, Austin - Boston - Chicago - New York - The Netherlands 2008, s. 1144-1145.

28 Por. np. P. Czechowski, (w:) P. Czechowski, M. Korzycka-Iwanow, S. Prutis, A. Stelmachowski, Polskie prawo rolne na tle prawodawstwa Unii Europejskiej, Warszawa 2002, s. 197-198; A. Jurcewicz, (w:) A. Jurcewicz, B. Kozłowska, E. Tomkiewicz, Polityka rolna..., op. cit., s. 44; J.A. Usher, Legal Aspects of Agriculture in European Community, Oxford 1988, s. 40-41.

29 Por. K. Lynggaard, The institutional construction of policy field: a discursive institutional perspective on change within the common agricultural policy, „Journal of European Public Policy” 2007, v. 14, nr 2, s. 293-294.

30 Por. A. Jurcewicz, (w:) D. Miąsik, N. Półtorak (red.), Traktat ustanawiający Wspólnotę Europejską. Komentarz, t. I, LEX 2008, s. 714. Wskazać należy, że ten kontekst dobitnie eksponowany jest w orzecznictwie Trybunału Sprawiedliwości. W szczególności na tle wykładni art. 38 ust. 2 TFUE (art. 32 ust. 2 TWE, art. 38 ust. 2 TEWG) wskazywano na związanie funkcjonalne pomiędzy regulacjami tworzącymi rynek wewnętrzny (przede wszystkim swobodami traktatowymi) a działaniami sektorowymi podejmowanymi na poziomie krajowym i unijnym (wspólnotowym) w odniesieniu do rolnictwa. Zob. w tej kwestii m.in. wyroki: z dnia 10 października 1973 r. w sprawie 34/73 Fratelli Variola S.p.A. przeciwko Amministrazione italiana delle Finanze, „Zbiór Orzeczeń” 1973, s. 981; z dnia 7 marca 1972 r. w sprawie 84/71 SpA Marimex przeciwko Ministero delle Finanze, „Zbiór Orzeczeń” 1972, s. 89; z dnia 13 grudnia 1973 r. w połączonych sprawach 37 i 38/71 Sociaal Fonds voor de Diamantarbeiders przeciwko NV Indiamex i Feitelijke Vereniging De Belder, „Zbiór Orzeczeń” 1973, s. 1609; z dnia 20 kwietnia 1978 r. w połączonych sprawach 80 i 81/77 Société Les Commissionnaires Réunis SARL przeciwko Receveur des douanes; SARL Les fils de Henri Ramel przeciwko Receveur des douanes, „Zbiór Orzeczeń” 1978, s. 927; z dnia 10 grudnia 1974 r. w sprawie Charmasson przeciwko Ministre de l'économie et des finances, „Zbiór Orzeczeń" 1974, s. 1383; z dnia 29 listopada 1978 r. w sprawie 48/74 Pigs Marketing Board przeciwko Raymond Redmond, „Zbiór Orzeczeń” 1978, s. 2347; z dnia 6 października 1987 r. w sprawie 118/86 Openbaar Ministerie przeciwko Nertsvoederfabriek Nederland BV, „Zbiór Orzeczeń” 1987, s. 3883; z dnia 11 czerwca 1985 r. w sprawie 288/83 Komisja Wspólnot Europejskich przeciwko Irlandii, „Zbiór Orzeczeń” 1985, s. 1761; z dnia 5 marca 1996 r. w połączonych sprawach C-46/93 i C-48/93 Brasserie du Pêcheur SA przeciwko Bundesrepublik Deutschland i The Queen przeciwko Secretary of State for Transport, ex parte: Factortame Ltd i innym, „Zbiór Orzeczeń" 1996, s. I-1029, z dnia 16 marca 1977 r. w sprawie 68/76 Komisja Wspólnot Europejskich przeciwko Republice Francuskiej (tzw. sprawa „Potates”), „Zbiór Orzeczeń” 1977, s. 515. 
integracji europejskiej, właściwym jest zatem zjawisko nakładania się płaszczyzn regulacyjnych, wyrażające się w zastosowaniu oddziaływania sektorowego, przy jednoczesnym dążeniu prawodawcy unijnego do utrzymania względem wszystkich sektorów gospodarki unijnej (w tym również rolnictwa) jednolitych ram normatywnych wyznaczających funkcjonowanie rynku wewnętrznego ${ }^{31}$.

„Rozgraniczenie” wynikające z konieczności uwzględnienia odmienności rolnictwa w kontekście stosowania ponadsektorowych rozwiązań dotyczących funkcjonowania rynku wewnętrznego odnosiło się również do kwestii ochrony konkurencji. Wyrazem tego podejścia jest art. 42 akapit 1 TFUE, który przyznaje Parlamentowi Europejskiemu i Radzie kompetencję do stanowienia sektorowych rozwiązań dotyczących ochrony konkurencji w sposób umożliwiający uwzględnienie w tym obszarze zadań związanych z realizacją celów WPR ${ }^{32}$. Przepis ten wyraża zatem normę kompetencyjną, na mocy której instytucje unijne (Parlament Europejski i Rada) mogą stanowić odrębne dla rolnictwa reguły konkurencji. Modyfikacja przyjętych w Traktacie generalnych reguł ochrony konkurencji wyraża się we wprowadzeniu stosownych wyłączeń dla sektora rolnego w zakresie niezbędnym dla realizacji celów $\mathrm{WPR}^{33}$. Przyjęte rozwiązanie przyznaje zatem preferencję celom WPR w materii ochrony konkurencji w sektorze rolnym ${ }^{34}$. Znaczące jest to, że przepis art. 42 TFUE nie przesądza co do zakresu, w jakim wyłączeniu podlegać ma stosowanie generalnych reguł konkurencji w odniesieniu do sektora rolnego. Stanowi to konsekwencję przyjmowanego w Traktatach ramowego charakteru rozwiązań dotyczących polityki rolnej i przyznania organom unijnym szerokich uprawnień dyskrecjonalnych przy precyzowaniu rozwiązań normatywnych właściwych dla realizacji celów z art. 39 TFUE.

31 Wśród przedstawicieli doktryny prawa rolnego trafnie zwraca się uwagę, że specyfika i jednocześnie trudność w podejściu regulacyjnym do rolnictwa wynika z poszukiwania spójności pomiędzy uniwersalnymi rozwiązaniami dotyczącymi sfery gospodarowania a partykularnymi rozwiązaniami nastawionymi na rozwiązanie problemów właściwych do tego sektora. Tak przede wszystkim: R. Budzinowski, Sprzeczności rozwojowe prawa rolnego, „Przegląd Prawa Rolnego” 2008, nr 2, s. 22-24. Autor ten wskazuje na dwupłaszczyznowość oddziaływania normatywnego na rolnictwo. Efektem tego są zjawiska uniwersalizacji i partykularyzacji prawa rolnego. Uniwersalizacja wyraża się w tym, że sektor rolnictwa poddany jest oddziaływaniu regulacji wspólnych dla wszystkich działów gospodarki. Partykularyzacja prawa rolnego wyraża się natomiast w tym, że regulacji prawa rolnego nadaje się charakter odrębny; właściwy wyłącznie dla tego obszaru gospodarki.

32 Artykuł 42 akapit 1 in fine TFUE wskazuje wprost, że działania legislacyjne w kwestii wyznaczenia reguł konkurencji w rolnictwie powinny następować $z$ uwzględnieniem celów WPR.

33 Por. np. E. Kosiński, Rodzaje i zakres..., op. cit., s. 312.

34 Por. D. Bianchi, La politique agricole commune (PAC). Précis de droit agricole européen, Bruxelles 2012, s. 173 oraz wyrok TS z dnia 5 października 1994 r. w sprawie C-280/93 Republika Federalna Niemiec przeciwko Radzie Unii Europejskiej, „Zbiór Orzeczeń” 1994, s. I-4973; wyrok TS z dnia 29 października 1980 r. w sprawie 139/79 Maizena GmbH przeciwko Radzie Wspólnot Europejskich, „Zbiór Orzeczeń” 1980, s. 3393. 


\section{Podejście do ochrony konkurencji z perspektywy prawa pochodnego UE}

Z art. 42 TFUE nie można wyprowadzić wniosków, które pozwalałyby na wytyczenie in concreto zakresu ochrony konkurencji, jaki został przewidziany przez prawodawcę unijnego dla sektora rolnego. W oparciu o ten przepis dochodzi natomiast do przeniesienia na płaszczyznę prawa pochodnego rozstrzygnięć w przedmiocie określenia relacji pomiędzy rozwiązaniami służącymi ochronie konkurencji a celami oraz - co stanowi konsekwencję występowania powyższej zależności - wyznaczenia zakresu stosowania normatywnych instrumentów ochrony konkurencji w sektorze rolnym. Oznacza to, że reguły konkurencji dla rolnictwa unijnego wynikają z przepisów prawa pochodnego stanowionych przez Parlament Europejski i Radę ${ }^{35} \mathrm{w}$ oparciu o kompetencję prawodawczą wywodzoną z art. 42 akapit $1 \mathrm{TFUE}^{36}$.

Reguły konkurencji w rolnictwie mają swoje umocowanie w rozporządzeniu nr 1308/2013 ustanawiającym wspólną organizację rynków produktów rolnych ${ }^{37}$ oraz rozporządzeniu nr 1184/2006 dotyczącym stosowania niektórych reguł konkurencji w odniesieniu do produkcji rolnej i handlu produktami rolnymi ${ }^{38}$. Akty te stanowią przejaw realizacji kompetencji prawodawczych z art. 42 akapit 1 TFUE. W aspekcie merytorycznym opierają się one na wyznaczaniu odrębnego reżimu stosowania ogólnych (generalnych) reguł konkurencji w odniesieniu do produkcji rolnej i handlu produktami rolnymi poprzez wyłączenie ich stosowania w przypadkach enumeratywnie wskazanych w tych rozporządzeniach (art. 2 rozporządzenia nr 1184/2006 oraz art. 209 i art. 210 rozporządzenia nr 1308/2013). Rozporządzenia przewidują, że w odniesieniu do rolnictwa następuje częściowe wyłączenie stosowania generalnych reguł konkurencji. Wobec braku podstaw do zastosowania wyłączeń przewidzianych w rozporządzeniach stosowane są generalne reguły konkurencji ${ }^{39}$. Zgodnie $\mathrm{z}$ art. 1 rozporządzenia nr 1184/2006, przepisy art. 81-86 TWE (obecnie art. 101-106

Wskazać należy, że na skutek zmian traktowych modyfikacji ulegał krąg podmiotów uprawnionych do określenia zakresu stosowania ogólnych reguł konkurencji dla rolnictwa. Pierwotnie kompetencja w tym zakresie przysługiwała Radzie. Następnie, w związku ze zmianami w zakresie podziału kompetencji prawodawczych w ramach WPR, kompetencję do wyznaczenia sektorowych reguł konkurencji przyznano Parlamentowi Europejskiemu i Radzie. Włączenie Parlamentu Europejskiego w procesy prawodawcze w ramach WPR, o czym była mowa w poprzednim rozdziale, stanowi odzwierciedlenie narastającej tendencji do wzmacniania elementów demokratycznych w procedurze prawotwórczej Unii Europejskiej.

36 Zgodnie z art. 42 akapit 1 TFUE realizacja tej kompetencji prawodawczej następuje z zachowaniem wymogów proceduralnych określonych $w$ art. 43 ust. 2 TFUE.

37 Rozporządzenie Parlamentu Europejskiego i Rady (UE) nr 1308/2013 z dnia 17 grudnia 2013 r. ustanawiające wspólną organizację rynków rolnych oraz uchylające rozporządzenia Rady (EWG) nr 922/72, (EWG) 234/79, (WE) nr 1037/2001 i (WE) nr 1234/2007, Dz. Urz. UE 2013 L 347 z 20 grudnia 2013 r., s. 671.

38 Rozporządzenie Rady (WE) nr 1184/2006 z dnia 24 lipca 2006 r. dotyczące stosowania niektórych reguł konkurencji w odniesieniu do produkcji rolnej i handlu produktami rolnymi, Dz. Urz. UE 2006 L 214 z 4 sierpnia 2006 r., s. 7.

E. Kosiński, Rodzaje i zakres..., op. cit., s. 103-104. 
TFUE), jak również przepisy stanowione w celu ich wykonania, mają zastosowanie do produkcji lub handlu produktami rolnymi ${ }^{40}$. Rozporządzenie przewiduje także, że do sektora rolnego zastosowanie mają przepisy traktatowe dotyczące udzielania pomocy państwowej (art. 3 rozporządzenia). Podobne założenia koncepcyjne w przedmiocie wyznaczenia reguł konkurencji mających zastosowanie do rolnictwa przewiduje rozporządzenie $\mathrm{nr}$ 1308/2013. W treści tego rozporządzenia wskazuje się, że generalne reguły konkurencji dotyczące przedsiębiorstw oraz pomocy państwa mają zastosowanie do produkcji i obrotu produktami rolnymi w ramach wspólnej organizacji rynków rolnych z zastrzeżeniem wyjątków przewidzianych w rozporządzeniu (art. 206 ust. 1 oraz art. 211 rozporządzenia nr 1308/2013). Rozporządzenie przesądza zatem o transponowaniu w ramy funkcjonowania sektora rolnego normatywnych instrumentów ochrony konkurencji, które są właściwe dla innych obszarów gospodarki unijnej (ogólnych reguł konkurencji). Wyjątki w stosowaniu generalnych reguł konkurencji, stanowiące odzwierciedlenie specyfiki sektora rolnego i dążenia do właściwej realizacji celów unijnej polityki rolnej, dotyczą wyłącznie przypadków wskazanych w treści rozporządzenia (tzn. ogólne wyłączenia stosowania generalnych reguł konkurencji dotyczących przedsiębiorstw, wyłączenia dotyczące określonych kategorii produktów rolnych oraz wyłączenia stosowania generalnych reguł konkurencji dotyczących przedsiębiorstw w okresie kryzysu na rynkach produktów rolnych).

Dla obu przywołanych rozporządzeń wyróżniające jest, że zakładają one częściowe wyłączenie stosowania generalnych reguł konkurencji do sektora rolnego. Przyjmuje się w nich - jako zasadę - że ogólne reguły konkurencji wyznaczane przez art. 101-109 TFUE (reguły konkurencji dotyczące przedsiębiorstw oraz pomocy publicznej) oraz stanowione $\mathrm{w}$ oparciu o nie akty prawa pochodnego mają zastosowanie wobec unijnego sektora rolnego. Wyłączenie ich stosowania dotyczy jedynie nielicznych przypadków wskazanych w treści rozporządzeń. W rozporządzeniach przesądza się zatem o szerokim stosowaniu do rolnictwa „ogólnych” rozwiązań służących ochronie konkurencji (stosowaniu art. 101-109 TFUE), co jest równoznaczne z przyjmowaną dla rolnictwa zasadniczo tożsamą oceną zjawisk godzących w mechanizm konkurencji jak ta, która przyjmowana jest w odniesieniu do innych obszarów gospodarki unijnej. Oznacza to, że wobec rolnictwa - poza ,sektorowymi" wyłączeniami stosowania generalnych reguł konkurencji, które mają swoje umocowanie $w$ regulacji prawnorolnej, tj. rozporządzeniu nr 1308/2013 (podstawowe wyłączenia stosowania reguł konkurencji - art. 209 i 210 rozporządzenia, wyłączenia w okresie kryzysu na rynku produktów rolnych - art. 222 rozporządzenia, a także wyłączenia na rzecz organizacji producentów rolnych oraz stowarzyszeń mień, praktyk i decyzji ograniczających konkurencję (art. 2 rozporządzenia). 
organizacji producentów rolnych we wszystkich sektorach dla potrzeb planowania produkcji i negocjowania dostaw - art. 152 ust. 1a rozporządzenia ${ }^{41}$ ) oraz rozporządzeniu nr 1184/2006 - zastosowanie znajdują również wyłączenia i odstępstwa przewidziane w ramach ogólnego reżimu ochrony konkurencji (blokowe wyłączenia stosowania zakazów oraz indywidualne odstępstwa realizowane na podstawie art. 101 ust. 3 TFUE) $)^{42}$. W konsekwencji stwierdzenie, że aktywność rynkowa podmiotów sektora rolnego nie podlega pod wyłączenia przewidziane w obrębie regulacji prawnorolnej (rozporządzenie nr 1308/2013 albo rozporządzenie nr 1184/2006) nie przesądza bezpośrednio o traktowaniu praktyk antykonkurencyjnych w sektorze rolnym jako sankcjonowanych przez art. 101 ust. 1 i art. 102 ust. 2 TFUE. Stosowanie generalnych reguł konkurencji do rolnictwa unijnego wiąże się z możliwością powoływania się na wyłączenia i odstępstwa przewidziane w obrębie tego reżimu prawnego ochrony konkurencji ${ }^{43}$. Tym samym, wobec kreowania przez rozporządzenie nr 1308/2013 oraz rozporządzenie nr 1184/2006 systemu częściowego wykluczenia stosowania generalnych reguł konkurencji, przy ocenie zachowań rynkowych podejmowanych w obrębie unijnego sektora rolnego konieczne jest również uwzględnienie implikacji wynikających z ogólnego reżimu ochrony konkurencji ${ }^{44}$.

Zaznaczenia wymaga, że na mocy normy kompetencyjnej zawartej w art. 42 TFUE, poza zagadnieniami dotyczącymi stosowania generalnych reguł konkurencji związanych z antykonkurencyjnymi praktykami przedsiębiorstw, pod szczególny reżim regulacji sektorowej dotyczącej rolnictwa włączone zostały także zagadnienia odnoszące się do subwencjonowania przez państwa członkowskie produkcji i handlu produktami rolnymi. Zarówno rozporządzenie nr 1184/2006, jak też rozporządzenie nr 1308/2013 zawierają postanowienia, które wyznaczają zakres stosowania do sektora rolnego przepisów Traktatu dotyczących działalności subwencyjnej państw członkowskich (art. 211-218 rozporządzenia nr 1308/2013 oraz art. 3 rozporządzenia nr 1184/2006). W ten sposób, w oparciu o przywołane akty prawne, dokonuje się realizacji wynikającego z art. 42 akapit 1 TFUE obowiązku Parlamentu Europejskiego i Rady w kwestii dopuszczalności stosowania do produkcji i obrotu

41 Artykuł 152 ust. 1a został dodany do rozporządzenia nr 1308/2013 z dniem 1 stycznia 2018 r. na mocy rozporządzenia Parlamentu Europejskiego i Rady nr 2017/2393 z dnia 13 grudnia 2017 r. zmieniającego rozporządzenia nr 1305/2013 w sprawie wsparcia rozwoju obszarów wiejskich przez Europejski Fundusz Rolny na rzecz Rozwoju Obszarów Wiejskich (EFRROW), nr 1306/2013 w sprawie finansowania wspólnej polityki rolnej, zarządzania nią i monitorowania, nr 1307/2013 ustanawiające przepisy dotyczące płatności bezpośrednich dla rolników na podstawie systemów wsparcia w ramach wspólnej polityki rolnej, nr 1308/2013 ustanawiające wspólną organizację rynków produktów rolnych oraz nr 652/2014 ustanawiające przepisy w zakresie zarządzania wydatkami odnoszącymi się do łańcucha żywnościowego, zdrowia zwierząt i dobrostanu zwierząt oraz dotyczącymi zdrowia roślin i materiału przeznaczonego do reprodukcji roślin (Dz.U. L 350 z 2017, s. 15).

42 Por. An overview of European competition rules applying in agricucltural sector (DG COMP, June 2016), s. 2 [opracowanie dostępne w internecie na stronie http://ec.europa.eu/competition/sectors/agriculture/overview_european_competition_rules_agricultural_sector.pdf (data dostępu: 2 stycznia 2017 r.)].

43 A. Gerbrandy, S. de Vries, Agricultural Policy and EU Competition Law. Possibilities and Limits for Self-Regulation in the Diary Sector, Hague 2011, s. 28. 
produktami rolnymi przepisów Traktatu dotyczących reguł konkurencji, w tym także tych odnoszących się do udzielania pomocy państwowej ${ }^{45}$.

W odniesieniu do sektora rolnego nie neguje się a priori znaczenia środków stanowionych na poziomie krajowym w celu zapewnienia jego właściwego funkcjonowania. Zwraca się natomiast uwagę, że aktywność pomocowa stanowiona przez państwa członkowskie może odgrywać istotną rolę przy minimalizowaniu mankamentów rynków rolnych oraz zapewnieniu właściwej realizacji celów WPR ${ }^{46}$. Dla rolnictwa unijnego odwołanie się do subwencji krajowych traktuje się jako czynnik spójny z założeniami WPR, który zmierza do zapewnienia ochrony oraz rozwoju produkcji rolnej, a także sprzyja właściwemu kształtowaniu obszarów wiejskich. Oddziaływanie na sektor rolny za pośrednictwem instrumentów wsparcia krajowego nie może jednak pozostawać $\mathrm{w}$ sprzeczności z celami WPR oraz prowadzić do zniekształcenia konkurencji na rynku wewnętrznym. Z tej przyczyny zakres udzielania pomocy krajowej dla rolnictwa - jako istotny z perspektywy funkcjonowania unijnego sektora rolnego - został włączony w ramy unijnej polityki rolnej i podporządkowany szczególnemu reżimowi ochrony konkurencji stanowionemu dla tego obszaru (art. 42 TFUE).

\section{Projekt dyrektywy o nieuczciwych praktykach rynkowych w łańcuchu dostaw żywności}

Projekt dyrektywy o nieuczciwych praktykach rynkowych w łańcuchu dostaw żywności stanowi przejaw uwzględnienia przez prawodawcę unijnego nowej perspektywy oddziaływania na funkcjonowanie konkurencji w rolnictwie. Dotychczas, o czym była mowa powyżej, nacisk kładziono na zagadnienia związane $\mathrm{z}$ ochroną konkurencji w aspekcie strukturalnym i cenowym poprzez odwołanie się do problematyki stosowania generalnych reguł konkurencji (art. 101-109 TFUE). Jednak przy takim spektrum oddziaływania nie zawsze możliwe było ujęcie wszystkich czynników rzutujących na właściwe kreowanie relacji rynkowych w łańcuchu dostaw żywności. Instrumenty oddziaływania na konkurencję ujęte w ramach tzw. unijnych reguł konkurencji (art. 101-109 TFUE) nie ujmują bowiem tych zagadnień, które związane są z oceną relacji między uczestnikami łańcucha dostaw żywności (z perspektywy przyjmowanego przez prawodawcę unijnego systemu wartości). Zaznaczenia wymaga, że projekt dyrektywy nie stanowi realizacji uprawnień prawodawczych wynikających z art. 42 akapit 1 TFUE, gdyż przepis ten odnosi się wyłącznie do stosowania tzw. reguł konkurencji. Wprowadzenie dyrektywy wiązać się będzie

45 Por. B. Willemot, (w:) M. Heidenhain (red.), European State Aid Law, München 2010, s. 400; M. Cardwell, (w:) K. Bacon (red.), European Union Law of State Aid, Oxford 2013, s. 281.

46 Por. Wytyczne Unii Europejskiej w sprawie pomocy państwa w sektorach rolnym i leśnym oraz na obszarach wiejskich w latach 2014-2020, publ. Dz.Urz. UE 2014 C 204/1, pkt 2. 
zatem z realizacją kompetencji prawodawczych określonych w art. 43 i zmierzających do realizacji celów WPR wyróżnionych w art. 39 TFUE.

W swoim zasadniczym założeniu dyrektywa kreuje zakaz podejmowania nieuczciwych praktyk handlowych w relacjach między przedsiębiorstwami w łańcuchu dostaw żywności. W ten sposób wyznacza się minimalny standard ochronny (art. 1 dykretywy) dla producentów rolnych, gdyż ze względu na swoją zatomizowaną strukturę i wynikającą z tego słabość przetargową podlegają oni często nieuczciwemu wykorzystywaniu przewagi kontraktowej. Inicjowana w ostatnich latach ewaluacja relacji rynkowych związanych z funkcjonowaniem łańcucha żywności wskazuje, że w jego obrębie ujawniają się zachowania podmiotów o silniejszym potencjale rynkowym, które polegają na narzucaniu nieuczciwych praktyk handlowych. Stanowią one odzwierciedlenie narastającej presji na zysk poprzez wykorzystanie marż handlowych i innych beneficjów przez nabywców. Podział korzyści związanych z produkcją i obrotem produktami rolnymi sprowadza się zatem do przejmowania korzyści przez podmioty działające na końcowym szczeblu łańcucha produkcji żywności. Odzwierciedleniem zaś tego stanu rzeczy jest niewłaściwa alokacja zasobów uzyskiwanych w procesie produkcji i obrotu produktami rolnymi.

Idea przewodnia dyrektywy sprowadza się do ujednolicenia standardu ochrony przed nieuczciwym wykorzystywaniem przewagi kontraktowej w łańcuchu dostaw żywności we wszystkich państwach członkowskich. Obecnie stosowane są zróżnicowane instrumenty dotyczące tej problematyki. W niektórych z nich stosowano ogólne rozwiązania służące zwalczaniu nieuczciwej konkurencji. Ogólne zakreślenie zakazu powoduje, że obejmuje on swoim zasięgiem również zachowania występujące w łańcuchu dostaw żywności. Natomiast w niektórych państwach członkowskich wprowadzono regulacje bezpośrednio dedykowane zagadnieniu nieuczciwego wykorzystania przewagi kontraktowanej w łańcuchu dostaw żywności. Jednak nie we wszystkich państwach następowało tożsame określenie tych praktyk, które stanowią przejaw nieuczciwego wykorzystywania przewagi kontraktowej.

Powyższy stan rzeczy determinował prawodawcę unijnego do zastosowania minimalnego standardu ochrony konkurencji w zakresie zwalczania nieuczciwych praktyk w lańcuchu dostaw żywności. Stąd też w projektowanej dyrektywie przewiduje się nałożenie na państwa członkowskie obowiązku wprowadzenia w ramach regulacji krajowych zakazów stosowania nieuczciwych praktyk handlowych w łańcuchu dostaw żywności w zakresie wyznaczonym (art. 3 dyrektywy). Nie wyklucza to jednak statuowania przez państwa członkowskie bardziej restrykcyjnych rozwiązań zmierzających do wzmocnienia pozycji dostawców w relacjach z nabywcami w łańcuchu dostaw żywności.

W kwestii przedmiotu regulowania wyróżniające jest to, że prawodawca unijny nie sprowadza koncepcji nieuczciwej praktyki rynkowej do kategorii relacji umow- 
nych. Pojęcie to ma szerszy charakter i dotyczy nie tylko realizacji stosownych postanowień umownych, ale również relacji przed- i pokontraktowych. Zakazane praktyki w projekcie dyrektywy różnicuje się na dwie kategorie.

$\mathrm{W}$ art. 3 ust. 1 przyjmuje się, że nieuczciwy charakter mają praktyki polegające na: 1) opóźnieniu w płatności na rzecz dostawców przez nabywców po upływie 30 dni, jeżeli dostawa dotyczy łatwo psujących się produktów; 2) anulowaniu zamówienia łatwo psujących się produktów spożywczych w tak krótkim czasie, że w sposób racjonalny można ocenić, iż dostawca nie będzie w stanie znaleźć alternatywnego sposobu zbycia lub wykorzystania tych produktów; 3) jednostronnych i z mocą wsteczną zmianach warunków umowy w zakresie częstotliwości dostaw, terminu i wielkości dostaw, standardów i jakości cen produktów rolnych; 4) obciążaniu dostawcy opłatami za marnotrawstwo produktów spożywczych, do którego dochodzi w siedzibie nabywcy i które nie jest spowodowane zaniedbaniem ani winą ze strony dostawcy. Dla tej kategorii praktyk wyróżniające jest to, że ich wystąpienie per se traktuje się jako mające walor praktyk nieuczciwych, a tym samym zakazanych w stosowaniu w relacjach handlowych w obrębie łańcucha dostaw żywności. Indyferentne znaczenie ma stwierdzenie, że stanowiły one przedmiot uzgodnień umownych między stronami.

Odmienny charakter mają natomiast praktyki określone w art. 3 ust. 2 projektowanej dyrektywy. Ich wystąpienie nie determinuje bezpośredniego wniosku, że stosowana praktyka ma charakter zakazany. Wprowadzenie takiej praktyki jest dopuszczalne, jeżeli jej przyjęcie stanowiło przedmiot jednoznacznego uzgodnienia przy zawieraniu umowy. Do tej kategorii zalicza się postanowienia umowne, w których: 1) nabywca zwraca niesprzedane produkty spożywcze dostawcy; 2) nabywca pobiera opłatę od dostawcy z tytułu przechowywania, prezentowania lub wystawiania na sprzedaż produktów spożywczych dostawcy; 3) dostawca płaci za promocję produktów spożywczych sprzedawanych przez nabywcę (przed promocją - jeżeli jest ona wdrażana przez nabywcę - nabywca określa czas trwania promocji oraz oczekiwaną ilość zamówionych produktów spożywczych); 4) dostawca płaci za obrót produktami spożywczymi przez nabywcę.

Projektowana dyrektywa zastosowanie powyższych zakazów ogranicza podmiotowo i przedmiotowo. Wbrew tytułowi dyrektywy nie obejmuje ona wszelkich form nieuczciwych praktyk handlowych, które mogą występować w łańcuchu dostaw żywności. W aspekcie podmiotowym dotyczy ona bowiem wyłącznie praktyk z udziałem małych i średnich przedsiębiorstw w rozumieniu określonym w załączniku do zalecenia Komisji 2003/361/WE14 ${ }^{47}$ jako dostawców w relacjach z nabyw-

47 Rozporządzenie Parlamentu Europejskiego i Rady (UE) nr 182/2011 z dnia 16 lutego 2011 r. ustanawiające przepisy i zasady ogólne dotyczące trybu kontroli przez państwa członkowskie wykonywania uprawnień wykonawczych przez Komisję (Dz.U. L 55 z 28.02.2011, s. 13). 
cami, którzy owego statusu małego lub średniego przedsiębiorstwa nie posiadają. Zakazane przez dyrektywę praktyki dotyczą przy tym relacji jednostronnej tzw. nieuczciwych praktyk wywołanych przez nabywców produktów spożywczych względem dostawców. Zaznaczyć jednak należy, że nieuczciwe praktyki handlowe w obrębie łańcucha dostaw żywności mogą wystąpić w różnych relacjach podmiotowych i nie redukują się wyłącznie do form i relacji opisanych w projektowanej dyrektywie. Stąd też państwom członkowskim pozostawia się możliwość „rozbudowania” katalogu tych zakazanych praktyk, które uznaje się za nieuczciwe w obrocie produktami żywnościowymi (art. 8).

$\mathrm{Na}$ tle projektowej dyrektywy konieczne jest również zwrócenie uwagi na zakres jej stosowania. Wskazać bowiem należy, że w swoim tytule dyrektywa wskazuje na szeroki zakres jej stosowania poprzez odwołanie się do praktyk handlowych w relacjach między przedsiębiorstwami w łańcuchu dostaw żywności. Tymczasem $\mathrm{z}$ art. 1 ust. 2 wynika, że dyrektywa będzie miała zastosowanie wyłącznie do nieuczciwych praktyk handlowych, które występują w związku ze sprzedażą produktów spożywczych przez dostawcę będącego małym lub średnim przedsiębiorstwem na rzecz nabywcy, który nie posiada statusu małego lub średniego przedsiębiorstwa. $\mathrm{W}$ projekcie pojęcie produktu żywnościowego ma charakter autonomiczny. Zakres tego pojęcia jest bowiem wyznaczany w oparciu o art. 2 lit. d projektowanej dyrektywy. $\mathrm{W}$ istocie jej stosowanie dotyczyć będzie produktów rolnych określonych w załączniku nr I do TFUE, które nadają się do spożycia oraz produktów z nich przetworzonych. Przedmiotem zainteresowania prawodawcy unijnego są zatem wyłącznie te transakcje handlowe, których przedmiotem jest określona kategoria produktu rolnego (tj. nadająca się do spożycia) albo produkty nadające się do spożycia powstałe w związku z przetworzeniem produktu rolnego. Mamy zatem do czynienia z lokowaniem tego rozwiązania normatywnego bezpośrednio w sferze regulacyjnej Wspólnej Polityki Rolnej, czego wyrazem jest oparcie kompetencji prawodawczej w tym zakresie na art. 43 TFUE. Zaznaczenia wymaga, że przy takim podejściu następuje rzeczywiste poszerzenie zakresu WPR. Wprawdzie zakres przedmiotowy WPR wyznacza kategoria pojęciowa ,produkt rolny” (art. 38 TFUE), to jednak dopuszczalne jest poszerzanie zakresu oddziaływania unijnej regulacji prawnorolnej poprzez odwołanie się do powiązania funkcjonalnego z produktem rolnym ${ }^{48}$.

W projekcie dyrektywy, poza obowiązkiem wprowadzenia w prawie krajowym zakazów określonych w art. 3, wymaga się od państw członkowskich wyznaczenia właściwego organu do egzekwowania prawa w zakresie zakazu wykorzystywania nieuczciwych praktyk handlowych w łańcuchu dostaw żywności. Ponadto,

48 Por. wyrok TS z dnia 2 lipca 2009 r. w sprawie C-343/07 Bavaria NV i Bavaria Italia Srl przeciwko Bayerischer Brauerbund eV, „Zbiór Orzeczeń” 2009 r., s. I-5491; wyrok TS z dnia 16 listopada 1989 r. w sprawie C-11/89 Komisja Wspólnot Europejskich przeciwko Radzie Wspólnot Europejskich, „Zbiór Orzeczeń” 1989, s. I-3799; wyrok TS z dnia 5 maja 1995 r. w sprawie C-180/96 Zjednoczone Królestwo Wielkiej Brytanii i Irlandii Północnej przeciwko Komisji Wspólnot Europejskich, „Zbiór Orzeczeń” 1998, s. I-2265. 
ze względu na to, że stwierdzenie występowania praktyki wymaga przeprowadzenia rozbudowanego postępowania dowodowego, projektowana dyrektywa zakłada wprowadzenie przez państwa członkowskie rozwiązań, które: 1) obligują organ egzekwujący do zachowania poufności co do danych identyfikujących skarżącego dostawcę (art. 5 ust. 1 i 3 projektowanej dyrektywy); 2) przyznają organowi egzekwującemu uprawnienia do prowadzenia postępowania i w jego ramach postępowania dowodowego, w tym również żądania przedłożenia przez dostawcę lub nabywcę wszelkich informacji niezbędnych dla prowadzenia dochodzenia (art. 6 lit. b).

Zgodnie z projektowaną dyrektywą, krajowy organ egzekwujący może wszcząć postępowania w sprawie nieuczciwego wykorzystywania przewagi kontraktowej z własnej inicjatywy lub na wniosek pochodzący od dostawcy lub organizacji producentów lub stowarzyszeń organizacji producentów, których członkowie uważają, iż w odniesieniu do nich nabywca zastosował nieuczciwą praktykę handlową (art. 5 ust. 1 i 2 oraz art. 6 lit. a). Organ jest też władny, po przeprowadzeniu stosownego postępowania, wydać decyzję stwierdzającą naruszenie zakazów określonych w art. 3 projektowanej dyrektywy i w jej ramach zobowiązać nabywcę do zaprzestania stosowania nieuczciwych praktyk handlowych. Możliwe jest również nałożenie grzywny na sprawcę naruszenia (art. 6 lit. d). Projektowana dyrektywa nie wprowadza jednak szczegółowych wytycznych dotyczących wysokości grzywny oraz zasad jej miarkowania. Zawiera jednakże wytyczne wskazujące na mechanizm określenia wysokości grzywny w przepisach krajowych oraz założeń dotyczących ich wymierzania przez organ egzekwujący. Przyjmuje się, że wysokość grzywny powinna być tak ustalana, aby była ona skuteczna, proporcjonalna i odstraszająca, a konkretyzacja tych przesłanek powinna następować poprzez odwołanie się do charakteru, czasu trwania i wagi naruszenia.

\section{Wnioski}

Uwzględniając obecną tendencję legislacyjną wskazać należy, że prawodawca unijny słusznie dostrzega konieczność wielopłaszczyznowego podejścia do kwestii ochrony konkurencji w rolnictwie. Zasadne jest również dostrzeżenie immanentnego związku między sektorem rolnym a sektorem produkcji i obrotu produktami żywnościowymi oraz zagrożeń dla rolników (producentów rolnych) w związku $\mathrm{z}$ ich funkcjonowaniem w łańcuchu dostaw żywności. Kreowane w oparciu o art. 42 TFUE rozwiązania sektorowe dotyczące stosowania unijnych reguł konkurencji (art. 101-109 TFUE) nie obejmują swoim zakresem regulowania zagadnień związanych $\mathrm{z}$ charakterem relacji rynkowych występujących w obrębie łańcucha dostaw żywności.

Podejmując się próby wstępnej oceny założeń koncepcyjnych wyrażonych w treści projektowanej dyrektywy wskazać należy, że stanowi ona wyraz trafnego 
podejścia prawodawcy unijnego do włączenia w zakres problematyki ochrony konkurencji w rolnictwie zagadnień dotyczących wartościowania relacji handlowych występujących w łańcuchu dostaw żywności. Mamy bowiem do czynienia z rozwiązaniem, które nastawione jest przede wszystkim na wzmocnienie pozycji producenta rolnego w obszarze produkcji żywności. W wymiarze praktycznym niezwykle istotne jest, że w dyrektywie dokonano wyróżnienia tych nieuczciwych praktyk rynkowych, które mają swoje odniesienie w obrębie tzw. łańcucha produkcji żywności. Eksponuje się w nich specyfikę produktu spożywczego związanego z ograniczeniami czasowymi dla spożycia. Ta cecha produktu spożywczego jest w praktyce często wykorzystywana przez nabywców dla wywierania presji na dostawcę. Ze względu na terminy przydatności do spożycia mają oni bowiem ograniczone możliwości poszukiwania alternatywnego miejsca zbytu. Na tle projektowanej dyrektywy ważne jest również podkreślenie, że zakłada ona ujednolicenie standardu ochrony przed nieuczciwymi praktykami we wszystkich państwach członkowskich.

Zaznaczyć w tym miejscu należy, że prezentowana powyżej ocena ma charakter wyjściowy. Trudno bowiem a priori przesądzić o faktycznych walorach regulacji, gdyż ich weryfikacja nastąpi dopiero poprzez stwierdzenie, jak przez organy egzekwujące stosowane są regulacje krajowe przyjęte w związku z wejściem w życie dyrektywy. Z dyrektywy nie wynika bowiem, że regulacje krajowe wprowadzane na jej podstawie mają mieć charakter wyłączny w odniesieniu do praktyk określonych w art. 3 albo, że mają one charakter „wyprzedzający” względem istniejących w krajowych porządkach prawnych rozwiązań dotyczących zwalczania nieuczciwej konkurencji. Nie jest zatem wykluczone, że przy identyfikacji i sankcjonowaniu nieuczciwych praktyk w łańcuchu dostaw żywności, mimo wejścia w życie kierunkowanej na te cele dyrektywy oraz stanowionych na jej podstawie regulacji krajowych, nadal będą preferowane przepisy krajowe statuujące (ogólny) reżim prawny zwalczania nieuczciwej konkurencji. 
LEGAL INSTRUMENTS OF PROTECTION COMPETITON IN THE AGRICULTURAL SECTOR IN UE LAW (OUTLINE OF THE ISSUES)

Keywords: Agricultural markets, rules of competition in agricultural sector, unfair trading practices in the food supply chain.

The article aims to analyse legal issues related to the protection of compettion in agriculture within the context of EU legislation. The conducted research was aimed at identifying motives justifying the sectoral approach adopted by the EU legislator to tackle the issue of protecting competition in agriculture, identifying adopted preferences and ways of determining the relationship between the objectives of the Common Agricultural Policy (CAP) and the competition policy within the scope of their impact on EU agriculture, as well as clarifying the content of rules of competition in agriculture derived from Art. 42 TFEU and secondary legislation established on its basis. Also the article aims to presentation new aspectes in the field of protection competition in agriculture wich express European Commission's proposal for a divective on unfair trading practices in business-to-business relationships in the food supply chain.

\section{Bibliografia:}

Adamowicz M., Król J., Ochrona konkurencji a rynek rolny, Warszawa 1998.

Barents R., Slot J.P., Sectoral Policies, (w:) P.J.G. Kapteyn, A.M. McDonnell, K.J.M. Mortelmans, C.W.A. Timmermans, L.A. Geelhoed (red.), The Law of European Union and European Communities, Austin - Boston - Chicago - New York - The Netherlands 2008.

Bianchi D., La politique agricole commune (PAC). Précis de droit agricole européen, Bruxelles 2012.

Budzinowski R., Sprzeczności rozwojowe prawa rolnego, „Przegląd Prawa Rolnego” 2008, nr 2.

Buhr B., Economics of Antitrust in An Era of Global Agri-Food Supply Chains: Litigate, Legislate and/or Facilitate?, „Drake Journal of Agricultural Law” 2010, v. 15, nr 1.

Cardwell M., (w:) K. Bacon (red.), European Union Law of State Aid, Oxford 2013.

Chen Y., Trade, Food Security, and Human Rights. The Rules of International Trade in Agricultural Products and Evolving World Food Crisis, Dorchester 2014.

Czechowski P., (w:) P. Czechowski, M. Korzycka-Iwanow, S. Prutis, A. Stelmachowski, Polskie prawo rolne na tle prawodawstwa Unii Europejskiej, Warszawa 2002.

Ennis S., Competition and Regulation in Agriculture, „OECD Journal of Competition Law and Policy" 2007, v. 9, nr 2.

Ganesh A.R., The Right to Food and Buyer Power, „German Law Journal” 2010, nr 11.

Gerbrandy A., de Vries S., Agricultural Policy and EU Competition Law. Possibilities and Limits for Self-Regulation in the Diary Sector, Hague 2011.

Gutiérrez Rodríguez J.D., Competition law goals in agricultural markets: a Latin America perspective, (w:) D. Zimmer (red.), The Goals of Competition Law, Cheltenham 2012. 
Johnston D.G., Competition in Agriculture: Fact or Fiction, „The American Economic Review” 1954, v. $44, \mathrm{nr} 2$.

Jurcewicz A., (w:) Jurcewicz A., Kozłowska B., Tomkiewicz E., Polityka rolna Wspólnoty Europejskiej w świetle ustawodawstwa i orzecznictwa, Warszawa 1995.

Jurcewicz A., Traktatowe podstawy unijnego prawa rolnego w świetle orzecznictwa. Zagadnienia wybrane, Warszawa 2013.

Komorowska D., Prawidłowości rozwoju rolnictwa a rozwój współczesnego rolnictwa, „Problemy Światowego Rolnictwa" 2014, t. 14, z. 3.

Kosiński E., Rodzaje i zakres sektorowych wyłączeń zastosowania ogólnych reguł konkurencji, Poznań 2007.

Kosiński E., Rolnictwo a publicznoprawna ochrona konkurencji w wybranych systemach prawnych (cz. I), „Kwartalnik Prawa Publicznego” 2005, nr 1-2.

Lauck J., Toward an Agrarian Antitrust: A New Direction for Agricultural Law, „North Dakota Law Review" 1999, v. 75.

Lynggaard K., The institutional construction of policy field: a discursive institutional perspective on change within the common agricultural policy, „Journal of European Public Policy” 2007, v. 14, nr 2.

McCorriston S., Competition and food security, The State of Agricultural Commodity Markets 2015-16, Food and Agriculture Organization of the United Nations (FAO) [raport dostępny na stronie internetowej: http://www.fao.org/3/a-i5225e.pdf (data dostępu: 21.12.2016 r.)].

Monti G., The relationships between CAP and competition policy. Does EU competition law apply to agriculture? COGECA Conference Helsinki Fair Trade, 13 November 2003.

Moss D.L., Taylor C.R., Short Ends of the Stick: The Plight of Growers and Consumers in Concentrated Agricultural Supply Chains, „Wisconsin Law Review” 2014, nr 1.

Pohorille M., Interwencjonizm w rolnictwie kapitalistycznym, Warszawa 1964.

Reich A., The Agricultural Exemption in Antitrust Law: a Comparative Look at the Political Economy of Market Regulation, „Texas International Law Journal” 2007, v. 42, nr 3.

Schütze R., From Dual to Cooperative Federalism. The Changing Structure of European Law, Oxford 2009.

Sexton R., McCorriston S., Wang S.H., Agricultural trade liberalization and economic development: the role of downstream market power, „Agricultural Economics” 2007, v. 36, nr 2.

Sokołowski J., Sosnowski M., Żabiński A. (red.), Polityka ekonomiczna, Warszawa 2012.

Sykuta M.E., The Fallacy of "Competition" in Agriculture, (w:) H.J. Jones Jr. (red.), The Goals of Competition Law, Cheltenham 2012.

Tomkiewicz E., (w:) D. Miąsik, N. Półtorak, Traktat ustanawiający Wspólnotę Europejską. Tom I (art. 1-160), Warszawa 2008.

Usher J.A., Legal Aspects of Agriculture in European Community, Oxford 1988.

Vanni F., Agriculture and Public Good. The Role of Collective Action, Dordrecht - Heidelberg - London - New York 2014.

Willemot B., (w:) M. Heidenhain (red.), European State Aid Law, München 2010.

Zegar J.S., Kategoria optymalności w rozwoju rolnictwa. Współczesne wyzwania, „Roczniki Nauk Rolnych Seria G” 2010, z. 3.

Zegar J.S., Konkurencyjność ekonomiczna versus konkurencyjność społeczna w rolnictwie, (w:) J. Sokołowski, M. Sosnowski, A. Żabiński (red.), Polityka ekonomiczna, Warszawa 2012. 